\section{Birlesik Dünya Arastrma Cypriot Journal of Educational \\ BD-CENTER \\ Sciences}

Innovasyon ve Yayıneılık Merkezi
Volume 16, Issue 6, (2021) 3133-3146

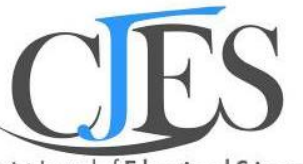

Cypriot Joumal of Educational Sciences

www.cjes.eu

\title{
The effect of cross-curricular integration on pupils' knowledge gained through experiential learning
}

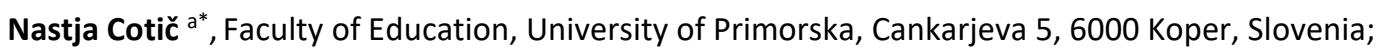
https://orcid.org/0000-0002-2916-0214

Mara Cotič b , University of Primorska, Faculty of Education, Cankarjeva 5, 6000 Koper, Slovenia; https://orcid.org/0000-0002-4958-4858

Darjo Felda c, Faculty of Education, University of Primorska, Cankarjeva 5, 6000 Koper, Slovenia; https://orcid.org/0000-0002-8588-0654

Nina Krmac ${ }^{\text {d }}$, Faculty of Education, University of Primorska, Cankarjeva 5, 6000 Koper, Slovenia; https://orcid.org/0000-0002-4507-210X

\section{Suggested Citation:}

Cotič, N., Cotič, M., Felda, D., \& Krmac, N. (2021). The effect of cross-curricular integration on pupils' knowledge gained through experiential learning. Cypriot Journal of Educational Science. 16(6), 3133-3146. https://doi.org/10.18844/cjes.v16i6.6512

Received from September 20, 2021; revised from November 22, 2021; accepted from December 12, 2021. (C)2021 Birlesik Dunya Yenilik Arastirma ve Yayincilik Merkezi. All rights reserved

\begin{abstract}
This study examined the effects of the cross-curricular model of integrating mathematics and science with experiential learning on the knowledge of 3rd grade primary school pupils in Slovenia. The purpose of this research was to design and implement school lessons rooted in integrating maths with science and concrete experience, and handling real objects. In the experimental group ( $\mathrm{N}=149$ ), maths and science lessons implemented a cross-curricular model which integrated experiential learning. In the control group $(\mathrm{N}=155)$, maths and science were taught as separate subjects without experiential learning. The data was collected with pre- and post-tests to establish pupils' knowledge. Differences between groups were analysed through MannWhitney $U$ test and Wilcoxon signed-rank test and showed that pupils from the experimental group performed better at the $2^{\text {nd }}$ and $3^{\text {rd }}$ TIMSS cognitive domain. Findings indicate that the cross-curricular learning model has a positive effect on pupil's achievement in science and mathematics.
\end{abstract}

Keywords: Cross-curricular integration, mathematics, science, experiential learning, TIMSS, cognitive domains.

\footnotetext{
* ADDRESS FOR CORRESPONDENCE: Nastja Cotič, University of Primorska, Cankarjeva 5, 6000 Koper, Slovenia: E-mail address: nastja.cotic@pef.upr.si / Tel.: +386-5663-12-60
} 


\section{Introduction}

\subsection{Theoretical framework}

According to the Council of European Union (2018), in today's society and economy memorisation of facts and procedures is no longer key; rather, it's important for people to have knowledge and skills allowing "problem solving, critical thinking, ability to cooperate, computational thinking and selfregulation" (Council of European Union, 2018, p. 2). These are the tools to make what has been learned in the education system work in real time in order to generate new ideas, new theories, new products and a new world (Council of European Union, 2018, p. 2). Thus, the curriculum should be functional in terms of content, allowing direct application in the classroom (Strmčnik, 2001) and set up students for a responsible life through forward-looking objectives and contents aligned with society's needs (Ivanuš Grmek et al., 2009).

School lessons play an important role in knowledge acquisition and development of pupils' capabilities and personalities (Tomić, 1997). For children, school is an important setting, and school work must be aligned with children's developmental principles and individual traits in all relevant areas. This is the only way to cultivate a personality whose bio-pyschosomatic status is well rounded in the physical, motor, cognitive, emotional and social sphere (Cotič et al., 2004). In the preschool period and beyond, a child experiences the world as a whole, and it is thus important to provide contents arising from real-life situations and based on experiential learning. Ross and Mannion (2012) referring to Jardine et al. (2008) indicate the need for the curriculum to be cross-curricular (integrated), include authentic activities rooted in real-life (Jardine et al., 2008), and firmly connecting school life with reallife experience.

Cross-curricular integration is an example of holistic learning and teaching, showing the real interactive world, its complexity, erasing the lines between school subjects, and supporting the principle that all knowledge is connected (Sicherl-Kafol, 2008). Cross-curricular integration increases the quality of the education process by being congruent with the child's development and learning. It improves school performance, facilitates deeper understanding and knowledge application, fosters sustainable knowledge and prepares the child for lifelong learning (Lake, 1994).

Well executed cross-curricular integrations prevent contents being repeated, and ensure permanent and high-quality knowledge. This didactic approach makes for far more motivated learners. The implementation of cross-curricular integration takes into account the child's overall development features and how children experience the world.

\subsection{Related research}

According to Felda \& Cotič (2012), it is important to nurture intuition, imagination, creativity, reasoning, planning etc. in every school subject at lower primary level as this stimulates the child's thinking. The teacher should make it a point to refer to problem-based situations occurring in the child's world and life. This applies to mathematical and scientific concepts as well; children will make an effort to understand them only if the problems are based in their own cognitive needs.

Different authors (Buluş Kirikkaya et al., 2010; Millar et al., 1998) maintain that science education should provide applicable knowledge, helping learners solve problems occurring in their daily life. The importance of science continues throughout primary school as pupils continue to develop critical and creative thinking (Murphy \& Beggs, 2005). Aside from that, they also develop the ability to observe, 
communicate, measure, experiment, classify, interpret data, form hypotheses, reason and predict (Murphy \& Beggs, 2005; Ongowo \& Indoshi, 2013).

In mathematics, they learn new mathematical notions, symbols, skills, concepts, strategies and process knowledge. Mathematical processes to be developed in maths classes are for example patternfinding, assessing results, breaking down complex problems to smaller chunks, reasoning, forming and confirming hypotheses, generalizing and proving. Apart from grasping mathematical notions and skills, the knowing and executing of mathematical processes is necessary to address problem-based situations to help the child gradually build a problem-solving strategy.

Thus, both maths and science are about building notions and making connections, getting to know and learn algorithms, allowing an individual to become integrated in the system of mathematical and scientific ideas, and ultimately embracing the respective culture they live in (Žakelj et al., 2011; Kolar et al., 2011). The authors recognize the effects of cross-curricular integration of maths and science, emphasizing that linking these subjects boosts learners' motivation, engagement and critical thinking, and strengthens problem-solving skills and critical assessment of examined concepts (Czerniak \& Johnson, 2014; Ríordáin et al., 2016).

The survey conducted by Treacy and O'Donoughe (2014) indicates that integrating maths with science (handling materials, group work, research and discussion) based on authentic experiences had a positive effect on pupils' understanding, and the teachers, who were included in the survey, expressed a positive view of this approach. In addition, in a survey by Sherrod et al. (2009) it was established that linking mathematics with science had a beneficial effect on pupils, most notably, that the activities gave pupils real-life skills. The activities designed gave pupils the chance to examine various science phenomena and at the same time calculate and analyse results (Sherrod et al., 2009). The survey conducted by Cotič et al. (2015) suggests statistically significant differences in favour of pupils who took part in integrated maths and science classes, with such pupils scoring higher in knowledge tests across all taxonomy levels compared to pupils who were covering the subject matter in separate subjects.

\subsection{Purpose of the study}

The purpose of this research was to design and implement school lessons rooted in integrating math with science and concrete experience, and handling real objects. Furthermore, it was sought to determine how our teaching model affected pupils' ability to solve math and science problems that were based on the TIMSS cognitive domains. The objective of the research was to examine how our lesson model, which is based on experiential learning by linking mathematics and science, affects pupils' knowledge of facts and procedures, their knowledge application and their reasoning compared to pupils who covered the topics (themes) in separate subjects (mathematics and environmental studies).

\section{Methods and materials}

\subsection{Research model}

To achieve the purpose of this study we formulated the following research hypotheses:

$\mathrm{H}$ : The experimental group of pupils will perform better in maths and science tasks compared to the control group.

Specific research hypotheses: 
$\mathrm{H} 1$ : The experimental group of pupils will perform better at maths and science problems relating to facts and procedures compared to the control group.

$\mathrm{H} 2$ : The experimental group of pupils will perform better at maths and science problems relating to the application of knowledge compared to the control group.

H3: The experimental group of pupils will perform better at maths and science problems relating to reasoning compared to the control group.

The research was designed as a non-randomized quasi-experimental research. The reasoning behind this choice was our belief that students are better served if they remain in their original classes, as the implementation of the research itself (specifically, the cross-curricular integration of mathematics and environmental studies) is new to them. Hence, we decided against breaking up existing classes, and rather conduct our research in the extant ones. Before conducting the research, we checked and confirmed the equivalence (Table 3 ) of the baseline mathematical and scientific knowledge of pupils across both groups (the experimental group (EG) and the control group (CG)). The experimental factor we introduced into our survey was the cross-curricular integration of mathematics and environmental studies based on experiential learning. The influence of our experimental factor was tested with a posttest incorporating mathematics and science topics. Figure 1 displays the course of our research (Figure 1).

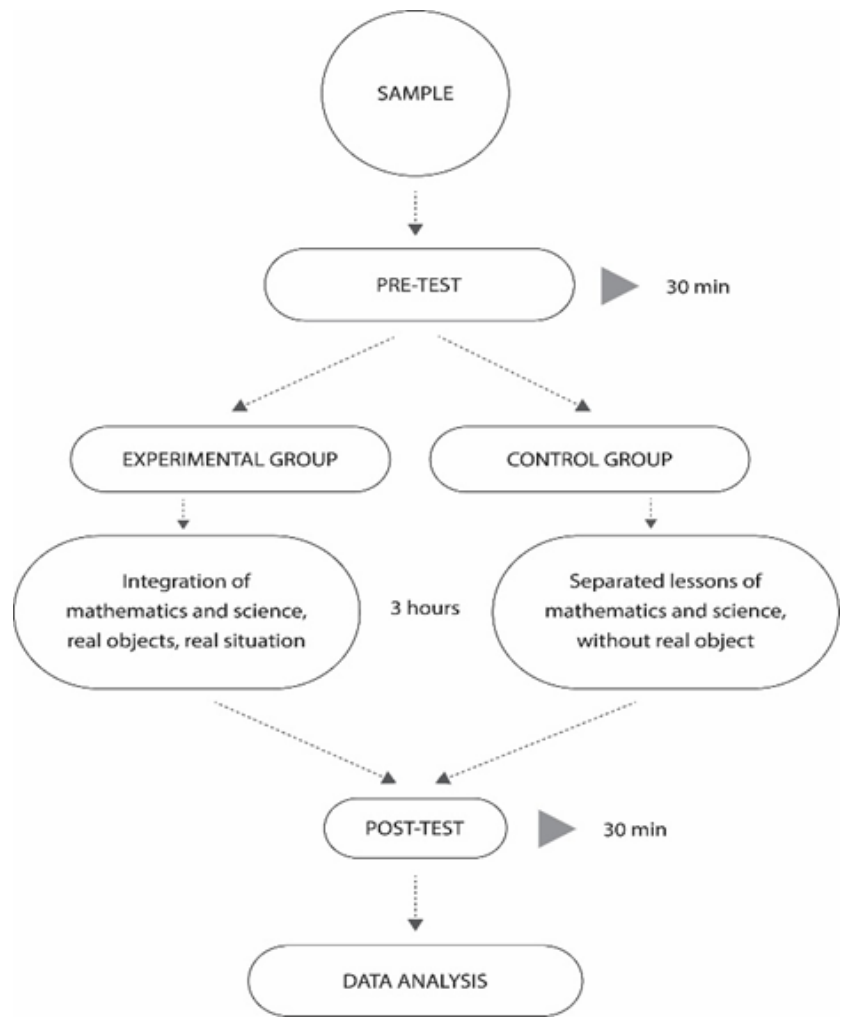

Figure 1. Flowchart of the research

The maths lessons of the EG covered the Logic and language, and environmental studies covered Living beings. The units and unit goals were combined to have the pupils first classify concrete items (seeds, fruits and tree leaves) according to various criteria, and then display this with different diagrams (Carroll, Euler-Venn and tree diagrams). 
It should be noted that this involved the concrete-experiential level, as the child's world consists mainly of concrete items and concrete operations. Pupils were asked to classify the items according to two properties. In doing so, they had to observe the individual fruits, seeds and leaves, and recognize the differences between them, learning more about each plant in the process. The CG covered the same mathematical and science topics, but used pictorial material rather than real objects and operations. The lessons therefore did not relate to their real life, and the topics were covered either in maths class or science class with no cross-curricular integration.

\subsection{Research participants}

The research included 306 third-grade pupils (with an average age of 8 years) across 9 Slovenian primary schools. 149 pupils were designated to be the EG and 155 to the CG. The research was carried out subject to a written consent of the parents and the school authorities. Anonymity was provided to all participants in the study.

\subsection{Data collections tools}

All research subjects, in both the EG and the CG took the pre-test and post-test measurements about mathematical and science knowledge. The pre-test sought to establish whether the groups have the same baseline knowledge. The pre-test included 3 assignments (Table 1). Every assignment earned four points.

Table 1. Pre - test

\begin{tabular}{|c|c|c|c|c|}
\hline \multirow[t]{2}{*}{ Assignment } & \multirow[t]{2}{*}{ Cognitive level } & \multirow{2}{*}{$\begin{array}{l}\text { Maximum } \\
\text { score }\end{array}$} & \multicolumn{2}{|c|}{ Learning objectives } \\
\hline & & & science & mathematics \\
\hline 1. & factual knowledge & 4 & $\begin{array}{l}\text { The child knows the } \\
\text { characteristics } \\
\begin{array}{l}\text { deciduous } \\
\text { coniferous trees. }\end{array}\end{array}$ & $\begin{array}{l}\text { The child can classify } \\
\text { items by one property. }\end{array}$ \\
\hline 2. & $\begin{array}{l}\text { conceptual } \\
\text { understanding }\end{array}$ & 4 & $\begin{array}{l}\text { The child is familiar with } \\
\text { autumn fruits and seeds } \\
\text { and can tell them apart; } \\
\text { the child also knows } \\
\text { where they belong. }\end{array}$ & $\begin{array}{l}\text { The child can classify by } \\
\text { one property and create } \\
\text { an appropriate display. }\end{array}$ \\
\hline 3. & reasoning and analysis & 4 & $\begin{array}{l}\text { The child is familiar with } \\
\text { the ecosystem and } \\
\text { animals belonging to it. }\end{array}$ & $\begin{array}{l}\text { The child identifies the } \\
\text { classifying characteristic. }\end{array}$ \\
\hline
\end{tabular}

After conducting the lesson with an experimental factor, pupils' knowledge was put to the test in the post-test (Table 2) which included mathematics and science assignments, with a focus on the topic discussed. Just like the pre-test, the post-test consisted of 3 assignments, each scoring 4 points. The maths lessons of the EG covered the Logic and language, and environmental studies covered Living beings. The units and unit goals were combined to have the pupils first classify concrete items (seeds, 
fruits and tree leaves) according to various criteria, and then display this with different diagrams (Carroll, Euler-Venn and tree diagrams).

\begin{tabular}{|c|c|c|c|c|}
\hline \multirow[t]{2}{*}{ Assignment } & \multirow[t]{2}{*}{ Cognitive level } & \multirow{2}{*}{$\begin{array}{l}\text { Maximum } \\
\text { score }\end{array}$} & \multicolumn{2}{|c|}{ Learning objectives } \\
\hline & & & science & mathematics \\
\hline 1. & factual knowledge & 4 & $\begin{array}{l}\text { The child classifies the } \\
\text { seeds and fruits in a } \\
\text { display according to two } \\
\text { properties. While } \\
\text { classifying, the child } \\
\text { observes the seeds and } \\
\text { fruits, and makes } \\
\text { comparisons. }\end{array}$ & $\begin{array}{l}\text { The child can classify by } \\
\text { two properties. }\end{array}$ \\
\hline 2. & $\begin{array}{l}\text { conceptual } \\
\text { understanding }\end{array}$ & 4 & $\begin{array}{l}\text { The child is familiar with } \\
\text { autumn fruits and seeds } \\
\text { and can tell them apart, } \\
\text { the child also knows } \\
\text { where they belong. }\end{array}$ & $\begin{array}{l}\text { The child can classify by } \\
\text { two properties and } \\
\text { create an appropriate } \\
\text { display. }\end{array}$ \\
\hline 3. & reasoning and analysis & 4 & $\begin{array}{l}\text { The child identifies the } \\
\text { properties according to } \\
\text { which the animals were } \\
\text { classified. }\end{array}$ & $\begin{array}{l}\text { The child identifies the } \\
\text { two classifying } \\
\text { properties. }\end{array}$ \\
\hline & & & $\begin{array}{l}\text { The child is familiar with } \\
\text { the ecosystem and } \\
\text { animals belonging to it. }\end{array}$ & \\
\hline
\end{tabular}

It should be noted that this involved the concrete-experiential level, as the child's world consists mainly of concrete items and concrete operations. Pupils were asked to classify the items according to two properties. In doing so, they had to observe the individual fruits, seeds and leaves, and recognize the differences between them, learning more about each plant in the process. The CG covered the same mathematical and science topics, but used pictorial material rather than real objects and operations. The lessons therefore did not relate to their real life, and the topics were covered either in maths class or science class with no cross-curricular integration.

\subsection{Data collection process}

The instrument's reliability was verified by computing the Cronbach $\alpha$ coefficient. The value of Cronbach $\alpha$ coefficient ( $\alpha=.76$ ) proves the reliability of the instrument. Due to the small number of assignments, the factor analysis for assessing the reliability and validity was non-applicable for the preand post-test. With regard to this, we ensured content validity of both tests by designing the assignments according to the TIMSS cognitive domains: assignment one was "factual knowledge and procedures", assignment two was "conceptual understanding" and assignment three was "reasoning 
and analysis". Face validity was ensured by designing both tests based on research objectives that were set beforehand.

Objectivity was ensured with precise, uniform and unambiguous instructions on how to take the tests. The difficulty index was calculated for both tests. The difficulty index for the pre-test ranged between .47 and .60 . The average difficulty index was .54 . The difficulty index for the post-test ranged between .50 and .63 . The average difficulty index was .56.

\subsection{Data Analysis}

The collected data were processed by using the Statistical Package for Social Sciences (SPSS). The following methods were applied for data processing:

- basic descriptive statistics,

- $\quad$ non-parametric tests: the Mann-Whitney $U$ test and Wilcoxon signed-rank test (because the conditions of the normality of distribution $(p>.05)$ and of the assumption of the equality of variance $(p$ $>$.05) were not fulfilled); Spearman's rank correlation coefficient.

\section{Results}

Table 3. Mann-Whitney U- test statistical parameters of the pupils' pre-test scores

\begin{tabular}{llccc}
\hline \multirow{2}{*}{ Groups } & $\mathrm{N}$ & Mean Rank & \multicolumn{2}{c}{ Mann-Whitney U test } \\
\cline { 4 - 5 } & & 150.08 & $U$ & $p$ \\
\hline CG & 155 & 155.02 & 11172.500 & .622 \\
\hline
\end{tabular}

There were no statistically significant differences in the baseline science knowledge between the EG and the CG $(U=11172.500 ; p=.622)$. Table 1 clearly shows that there were no statistically significant differences in solving items on the TIMSS cognitive domains. The pre-test scores of both groups were comparable prior to the experiment, which means that pupils from both groups had similar prior science knowledge.

Table 4. Mann-Whitney U test statistical parameters of the pupils' pre-test scores on the TIMSS cognitive domains

\begin{tabular}{|c|c|c|c|c|c|}
\hline \multirow[b]{2}{*}{ Cognitive domain } & \multirow[b]{2}{*}{ Groups } & \multirow[b]{2}{*}{$\mathrm{N}$} & \multirow[b]{2}{*}{ Mean Rank } & \multicolumn{2}{|c|}{ Mann-Whitney $U$ test } \\
\hline & & & & $U$ & $p$ \\
\hline \multirow{2}{*}{$\begin{array}{l}\text { Factual } \\
\text { knowledge }\end{array}$} & CG & 155 & 153.45 & \multirow[b]{2}{*}{11400.500} & \multirow[b]{2}{*}{.841} \\
\hline & EG & 149 & 151.51 & & \\
\hline \multirow{2}{*}{$\begin{array}{l}\text { Conceptual } \\
\text { understanding }\end{array}$} & CG & 155 & 149.54 & \multirow[t]{2}{*}{11088.000} & \multirow[t]{2}{*}{.526} \\
\hline & EG & 149 & 155.58 & & \\
\hline \multirow{2}{*}{$\begin{array}{l}\text { Reasoning } \\
\text { analysis }\end{array}$} & CG & 155 & 149.62 & \multirow[t]{2}{*}{11101.500} & \multirow[t]{2}{*}{.547} \\
\hline & EG & 149 & 155.49 & & \\
\hline
\end{tabular}

The table depicts the difference in values for each assignment based on the TIMSS cognitive domains for the CG and the EG. The values of the Mann-Whitney $U$ test indicate that between the pupils there was no statistically significant difference in any of the assignments $(U=11400.500, p=.841),(U=$ 
$11088.000, p=.526)$ and $(U=11101.500, p=.547)$, suggesting that there have been no differences between the pupils from the EG and CG in terms of their baseline knowledge as determined by the pretest that was based on cross-curricular integration of maths and science.

Table 5. Mann-Whitney U test statistical parameters of the pupils' post-test scores (on TIMSS cognitive domains)

\begin{tabular}{|c|c|c|c|c|c|}
\hline \multirow{2}{*}{ Cognitive domain } & \multirow{2}{*}{ Groups } & \multirow[b]{2}{*}{$\mathrm{N}$} & \multirow{2}{*}{ Mean Rank } & \multicolumn{2}{|c|}{ Mann-Whitney $U$ test } \\
\hline & & & & $U$ & $p$ \\
\hline \multirow[t]{2}{*}{ Factual knowledge } & CG & 155 & 105.66 & \multirow{2}{*}{11262.500} & \multirow{2}{*}{.697} \\
\hline & EG & 149 & 154.41 & & \\
\hline Conceptual & CG & 155 & 138.52 & 9381.000 & .003 \\
\hline understanding & EG & 149 & 167.04 & & \\
\hline Reasoning and & CG & 155 & 140.89 & 9748.500 & .016 \\
\hline analysis & EG & 149 & 164.57 & & \\
\hline
\end{tabular}

With regard to the first cognitive domain relating to factual knowledge, no statistically significant differences showed up between the EG and the CG $(U=11262.5000, p=.697)$. However, with regard to the second and third cognitive domain, statistically significant differences appeared for conceptual understanding $(U=9381.000, p=.003)$ and reasoning and analysis $(U=9748.500, p=.016)$. On both domains, EG pupils outperformed the CG.

Pupils could score a maximum of 4 points in each assignment, with all assignments being capped at four points. The graph below shows the average point score achieved on each cognitive domain by the EG and CG.

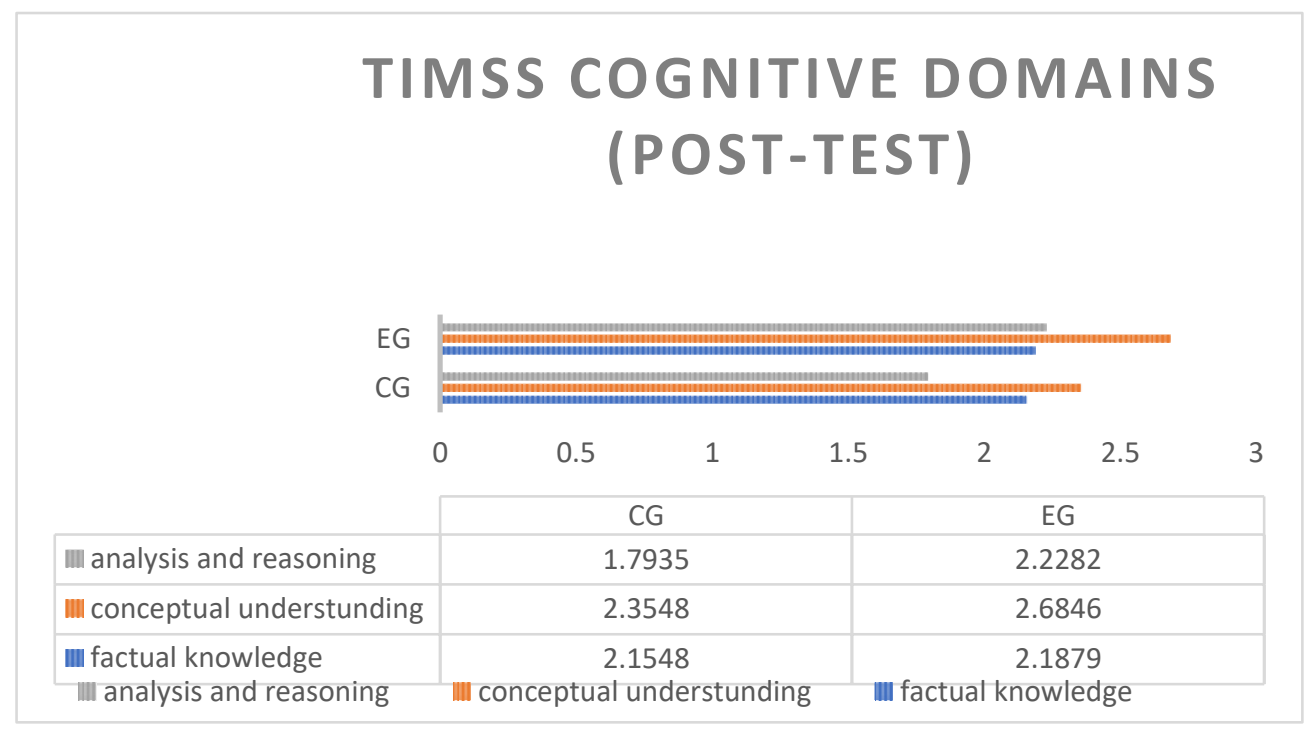

Figure 2. The average point score at each TIMSS cognitive domain for the EG and CG

The graph shows that, on average, pupils performed the best with the second assignment, i.e. at the second taxonomic level (conceptual understanding). This goes for both the EG and the CG.

Shown below are graphs for each cognitive domain and the relevant point score. 


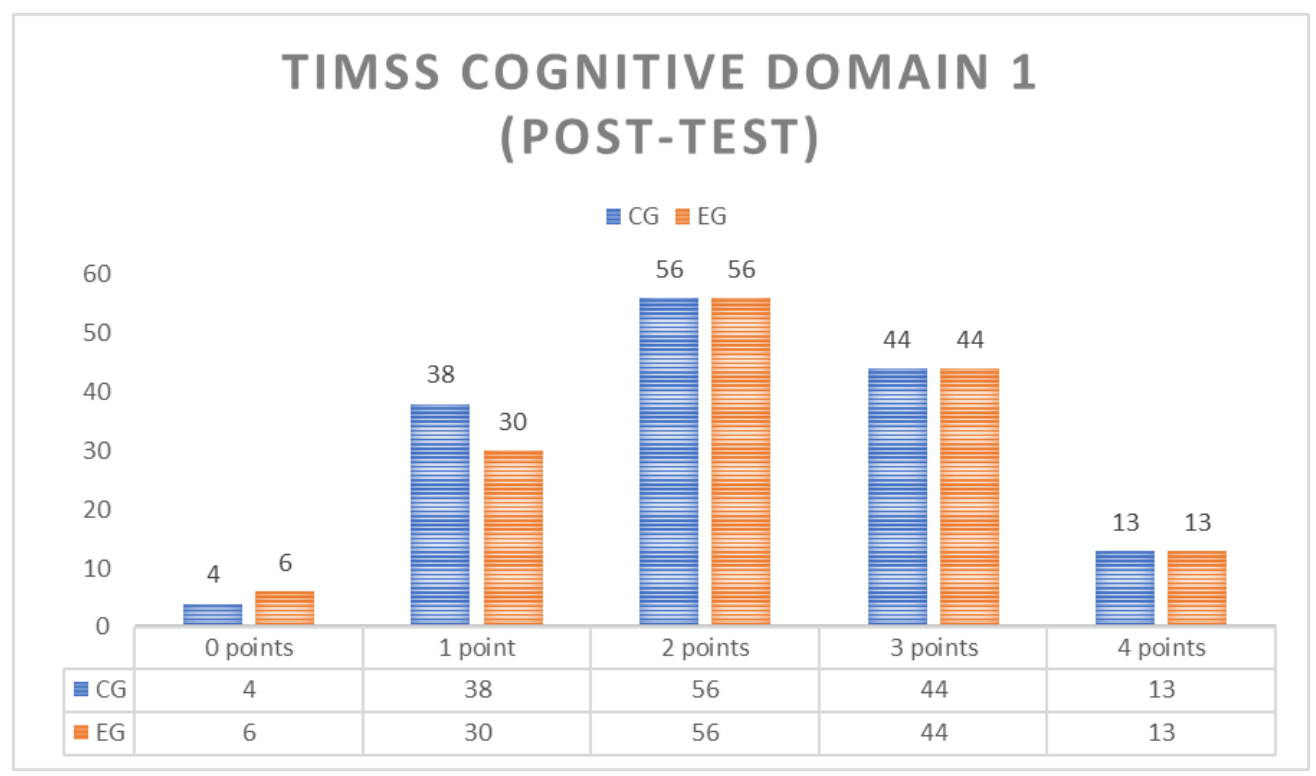

Figure 3. Point score of the EG and CG on the first TIMSS cognitive domain

The graph shows that the point score in the first assignment on the first cognitive domain is relatively similar in the EG and CG. In both groups - the control and the experimental one - the majority of pupils scored 2 points; specifically, 56 pupils from the EG and just as many from the CG.

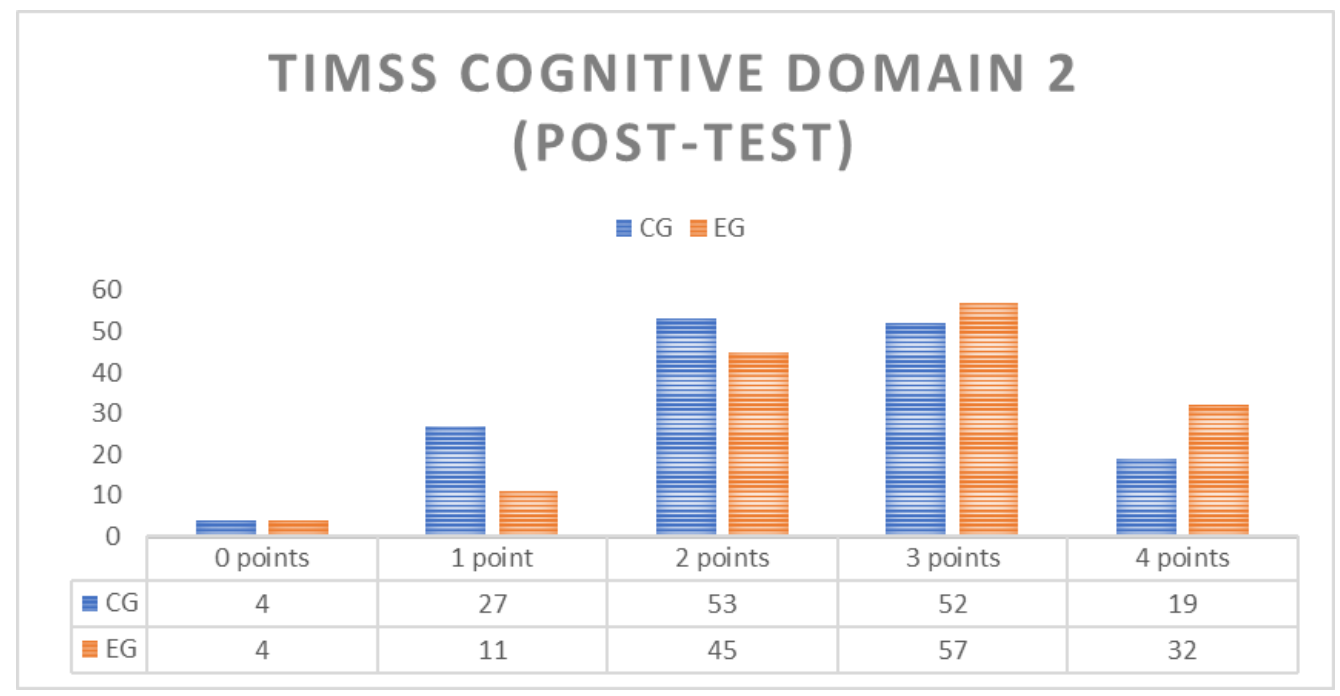

Figure 4. Point score of the EG and CG on the second TIMSS cognitive domain

With regard to the second assignment on the second cognitive domain, it was the experimental group's performance that stood out. In this assignment, 32 pupils from the EG and 19 pupils from the CG achieved the maximum score. 


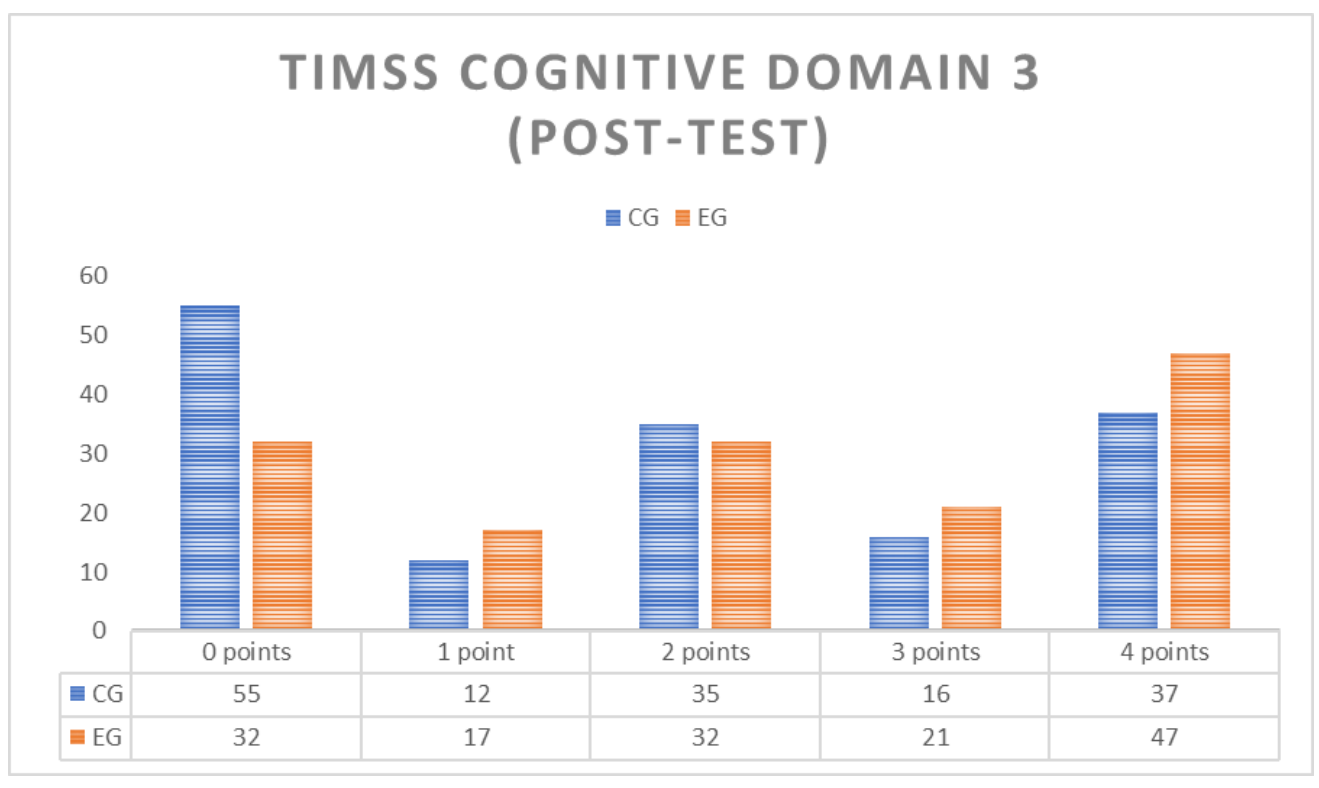

Figure 5. Point score of the EG and CG on the third TIMSS cognitive domain.

The post-test, which involved an assignment on the third cognitive domain, makes it clear that EG pupils had better results and achieved a higher point score. Out of a total of 149 pupils, 47 pupils from the EG solved the assignment entirely correctly, earning 4 points. Also in the EG, the assignment was solved entirely incorrectly by 32 pupils and by as many as 55 pupils in the CG out of a total of 155 . In the CG, 37 pupils solved the assignment entirely correctly.

Moreover, we were interested in the correlation in pupil performance in the pre-and post-test. The assumption was that pupils with a higher point score in the pre-test would achieve a higher point score in the post-test.

Table 6. The Spearman correlation coefficient of pupil performance in the pre-test and post-test

\begin{tabular}{llll}
\hline Group & Test & $r$ & $p$ \\
\hline KS & Pre-test & $.977^{* *}$ & $<.001$ \\
& Post-test & & \\
ES & $\begin{array}{l}\text { Pre-test } \\
\text { Post-test }\end{array}$ & $.896^{* *}$ & $<.001$ \\
& & & \\
\hline
\end{tabular}

Both correlation coefficients indicate a high correlation in pupil performance in the pre-test and posttest. The CG shows a very high or very strong correlation $(r=.977)$ in the pre-test and post-test performance. The lower correlation in the performance of the EG between the pre-test and post-test may indicate that experiential learning has helped pupils perform better through experiential learning than they would otherwise or compared to the pre-test.

Consequently, we were also interested in the progress of the pupils in the EG as the correlation was lower compared to the CG.

The Wilcoxon signed-ranks test was used to determine progress in EG pupils due to the availability of ordinal variables. 
Table 7. Pre-test and post-test results of the Wilcoxon ranks test regarding the progress of EG pupils

\begin{tabular}{|c|c|c|c|c|c|}
\hline & \multirow{2}{*}{ Rank } & \multirow{2}{*}{$\mathrm{N}$} & \multirow{2}{*}{ Mean Rank } & \multicolumn{2}{|c|}{ Wilcoxon Ranks Test } \\
\hline & & & & $Z$ & $p$ \\
\hline \multirow{5}{*}{ EG } & Negative & 14 & 25.46 & \multirow{5}{*}{-6.142} & \multirow{5}{*}{$<.001$} \\
\hline & Ranks & & & & \\
\hline & Positive & 65 & 43.13 & & \\
\hline & Ties & 70 & & & \\
\hline & Total & 149 & & & \\
\hline
\end{tabular}

The results of the Wilcoxon ranks test indicate that $14 \mathrm{EG}$ pupils had a lower score on the post-test. Meanwhile, 65 pupils scored higher on the post-test, and for 70 pupils there was no difference in the scores on the pre-test and the post-test. The value of the Wilcoxon ranks test $(Z=-6.142, p<.001)$ indicates that there are statistically significant differences regarding the progress of the $E G$ pupils.

The same calculation was performed for the CG pupils, determining that there have been no changes regarding the progress of their knowledge $(Z=-.596, p=0.551)$. This is evident form the table below.

Table 8. Pre-test and post-test results of the Wilcoxon ranks test regarding the progress of CG pupils

\begin{tabular}{|c|c|c|c|c|c|}
\hline & \multirow{2}{*}{ Rank } & \multirow{2}{*}{$\mathrm{N}$} & \multirow{2}{*}{ Mean Rank } & \multicolumn{2}{|c|}{ Wilcoxon Ranks Test } \\
\hline & & & & $Z$ & $p$ \\
\hline \multirow{6}{*}{ CG } & Negative & 21 & 21.40 & \multirow{6}{*}{-0.596} & \multirow{6}{*}{.551} \\
\hline & Ranks & & & & \\
\hline & Positive & 19 & 19.50 & & \\
\hline & Ranks & & & & \\
\hline & Ties & 115 & & & \\
\hline & Total & 155 & & & \\
\hline
\end{tabular}

In the post-test, 21 pupils achieved a lower point score, and 19 pupils a higher point score. Meanwhile, there was no difference in performance between the pre-test and post-test score in 115 pupils.

\section{Discussion}

Our research centered predominantly on experiential learning in integrated math and science lessons in primary school. As such, in addition to cross-curricular integration, we specifically homed in on the concrete experience and handling of concrete materials. For primary school pupils this is crucial, since children, when entering school, are at the concrete operational stage. This issue is also highlighted in the math syllabus (Žakelj et al., 2011) and the environmental studies syllabus (Kolar et al., 2011).

The pupil takes the central role beyond a passive listener, actively co-shaping their own teaching process. Despite the positive effects of active learning, there are still instances where teachers are just knowledge conveyors, with pupils relegated to passive listeners who are not encouraged to come up with their own solutions; as a result, there is no development of the child's cognitive abilities taking place nor a true grasp of mathematical and scientific concepts.

In the empirical part of our research, a carefully designed pedagogical experiment was conducted that drew on the results of domestic and foreign literature and a detailed analysis of the curricula for the first educational cycle of primary school, highlighting the opportunities for cross-curricular 
integration and experiential learning. An experiment was carried out to test whether the teaching and learning model currently in place is effective, whilst zooming in on reaching the objectives at higher taxonomic levels. Similar conclusions have been reached in various studies. Friend (1985) have found out that the integration of math and science had a positive effect on enjoyment of science learning and on achievement in science. Ross and Hogaboam-Gray (2011) also have found that the integration of math, science and technology increased students' motivation, ability to work together, and better learning outcomes. Al Orime and Ambusaidi (2011) have demonstrated that the use of integrate activities of math and science had a good impact on mathematical skills and processes, and to solve scientific problems in science.

Furthermore, this model promotes different types of interdisciplinary knowledge, which is increasingly relevant today. The research at hand and many other studies around the world emphasize the importance of cross-curricular integration, as it promotes a student-centred knowledge transfer, boosting student motivation (Rennie et al., 2013). Cross-curricular integration makes the pupil experience more relevant, less fragmented, and more stimulating. Integration provides more realistic and complete approach to teaching and topic (Davison et al., 1995; Akerson \& Flanigan, 2000). Not only that, cross-curricular teaching and learning supported by experiential learning cultivates advanced epistemological beliefs, improves critical thinking and metacognitive abilities, and nurtures understanding of relations between perspectives arising from different subject areas, all the while strengthening the ability to apply the knowledge acquired in each discipline. What is instrumental in all of this is that cross-curricular integrations must clearly tie in with real-life situations (Volk, 2019). Only in this way do we foster that kind of knowledge which helps the child, and later the adult, function in society.

\section{Conclusions}

Before commencing with the experiment, pupils' knowledge of mathematics and science, which is expected to be acquired by the end of the $2^{\text {nd }}$ grade, was tested. Next, the EG pupils were subjected to a fleshed-out teaching model involving units and contents integrating both science and mathematics through experiential learning. The lessons for the CG pupils took place according to the predefined annual lesson plan, where lessons take place in separate subjects and do not include cross-curricular teaching and experiential learning. At the end of the experiment, the pupils of both groups were asked to complete the post-test which included cross-curricular assignments.

The statistical analysis of the post-test results suggests that pupils of the EG who were involved in the fleshed-out model of cross-curricular teaching through experiential learning performed statistically significantly better when it came to solving cross-curricular assignments at the second and third TIMSS cognitive domains compared to pupils from the CG who were pursuing the same objectives through lessons where the subjects are separate and without experiential. No statistically significant differences in the performance were established in assignments at first TIMSS cognitive domain, indicating that our model fosters knowledge at higher taxonomic levels.

\section{Recommendations}

Based on the results of this study, it is recommended that teachers in Slovenian primary schools understand the meaning of cross-curricular teaching for students, integrate cross-curricular activities in their lessons, and increase the involvement of the experiential learning during lessons. 
Cotič, N., Cotič, M., Felda, D., \& Krmac, N. (2021). The effect of cross-curricular integration on pupils' knowledge gained through experiential learning. Cypriot Journal of Educational Science. 16(6), 3133-3146. https://doi.org/10.18844/cjes.v16i6.6512

\section{References}

Akerson, V. L., \& Flanigan, J. (2000). Preparing preservice teachers to use an interdisciplinary approach to science and language arts instruction. Journal of Science Teacher Education, 11(4), 345-362. https://doi.org/10.1023/A:1009433221495

Al Orime, S., \& Ambusaidi, A. (2011). The Impact of Using the Integration Approach between Science and Math on Acquiring the Skills for Solving Scientific Problems. Journal of Turkish Science Education, 8(2), 9-22.

Buluş Kırıkkaya,E., Bali, G., Bozkurt, E., İşeri, Ş., \& Vurkaya, G., (2010). Entertaining science summer school activities for primary pupils. In S. Dolinšek \& T. Lyons (Eds.), Socio-cultural and Human Values in Science and Technology Education (pp. 206-219). IRI UL, Institute for Innovation and Development of University of Ljubljana.

Cotič, M., Zurc, J., \& Kozlovič, D. (2004). Celosten pristop pri zgodnjem poučevanju-vloga gibalnih aktivnosti pri pouku matematike. [An integrated approach to early teaching-the role of motor activities in mathematics teaching]. Didactica Slovenica, 19(2), 32-46.

Cotič, N., Cotič, M., Felda, D., \& Lepičnik Vodopivec, J. (2015). An example of integrated teaching of mathematics and environmental education in the second grade of basic school. Stanisław Juszczyk, 41(3), 17-26.

Council of the European Union. (2018). Priporočila Sveta z dne 22. maja 2018 o ključnih kompetencah za vseživljensko učenje (2018/C189/01). [Council Recommendations of 22 May 2018 on key competences for lifelong learning]. Uradni list Evropske unije, C189/1-13.

Czerniak, C. M., \& Johnson, C. C. (2014). Interdisciplinary science teaching. Handbook of research on science education, 2, 395-411.

Davison, D. M., Miller, K. W., \& Metheny, D. L. (1995). What does integration of science and mathematics really mean?. School science and mathematics, 95(5), 226-230. https://doi.org/10.1111/j.19498594.1995.tb15771.x

Felda, D., \& Cotič, M. (2012). Zakaj poučevati matematiko. [Why teach math]. Revija za elementarno izobraževanje, 5(2/3), 107-120.

Friend, H. (1985). The Effect of Science and Mathematics Integration on Selected Seventh Grade Students' Attitudes Toward and Achievement in Science. School Science and Mathematics, 85(6), 453-61.

Ivanuš Grmek, M. Vukman, K. B., Cencič, M., Čagran, B., Krečič, M. J., Schmidt, M., \& Žakelj, A. (2009). Načrtovanje vzgojno-izobraževalnega procesa-koncepti načrtovanja kurikula: zaključno poročilo ciljno raziskovalnega projekta: (ciljni raziskovalni projekt V5-0437 v okviru Ciljnega raziskovalnega programa" Konkurenčnost Slovenije 2006-2013", ki sta ga financirala Javna agencija za raziskovalno dejavnost RS in Ministrstvo za šolstvo in šport). [Planning of the educational process-curriculum planning concepts: final report of the target research project: (target research project V5-0437 within the Target research program "Competitiveness of Slovenia 2006-2013", funded by the Public Research Agency of the Republic of Slovenia and the Ministry of Education Ljubljana]. Faculty of Education.

Jardine, D., Clifford, P., \& Friesen, S. (2008). Back to the basics of teaching and learning: Thinking the world together (2nd ed.). Routledge Press.

Kolar, M., Krnel, D., \& Velkavrh, A. (2011). Program osnovna šola Spoznavanje okolja Učni načrt. [Elementary school learning about the environment curriculum Slovenia]. Ljubljana. https://www.gov.si/assets/ministrstva/MIZS/Dokumenti/Osnovna-sola/Ucninacrti/obvezni/UN spoznavanje okolja pop.pdf

Lake, K. (1994). Integrated curriculum (School Improvement Research Series \#16). https://educationnorthwest.org/sites/default/files/IntegratedCurriculum.pdf 
Cotič, N., Cotič, M., Felda, D., \& Krmac, N. (2021). The effect of cross-curricular integration on pupils' knowledge gained through experiential learning. Cypriot Journal of Educational Science. 16(6), 3133-3146. https://doi.org/10.18844/cjes.v16i6.6512

Millar, R., Osborne, J., \& Nott, M. (1998). Science education for the future. School Science Review, 80(291), 19-24.

Murphy, C., \& Beggs, J. (2005). Primary science in the UK: A scoping study. Final report to the Wellcome Trust. Wellcome Trust.

Ongowo, R. O., \& Indoshi, F. C. (2013). Science process skills in the Kenya certificate of secondary education biology practical examinations. Creative Education, 4(11), 713-717. https://doi.org/10.4236/ce.2013.411101

Rennie, L., G., Venville, G., \& Wallace, J. (2013). Knowledge that counts in a global community: Exploring the contribution of integrated curriculum. Routledge. https://doi.org/10.4324/9780203817476

Ríordáin, M. N., Johnston, J., \& Walshe, G. (2016). Making mathematics and science integration happen: key aspects of practice. International Journal of Mathematical Education in Science and Technology, 47(2), 233-255. https://doi.org/10.1080/0020739X.2015.1078001

Ross, J. A., \& Hogaboam- Gray, A. (2011). Integrating mathematics, science, and technology: effects on students. International Journal of Science Education, 20(9), 1119-1135. https://doi.org/10.1080/0950069980200908

Ross, H., \& Mannion, G. (2012). Curriculum making as the enactment of dwelling in places. Studies in Philosophy and Education, 31(3), 301-313. https://doi.org/10.1007/s11217-012-9295-6

Sherrod, S. E., Dwyer, J., \& Narayan, R. (2009). Developing science and math integrated activities for middle school students. International Journal of Mathematical Education in Science and Technology, 40(2), 247-257. https://doi.org/10.1080/00207390802566923

Sicherl-Kafol, B. (2008). Medpredmetno povezovanje v osnovni šoli. [Cross-curricular integration in primary school]. Didacta, 18/19, 7-9. http://www.didakta.si/doc/revija didakta 2008 november.pdf

Strmčnik, F. (2001). Osrednje teoretične teme. [Central theoretical topics]. Scientific Institute of the Faculty of Philosophy.

Tomić, A. (1997). Izbrana poglavja iz didaktike. Študijsko gradivo za pedagoško andragoško izobraževanje. [Selected chapters from didactics. Study material for pedagogical andragogic education]. Centre for Pedagogical Education of the Faculty of Arts.

Treacy, P., \& O'Donoghue, J. (2014). Authentic Integration: a model for integrating mathematics and science in the classroom. International Journal of Mathematical Education in Science and Technology, 45(5), 703-718. https://doi.org/10.1080/0020739X.2013.868543

Volk, M. (2019). Medpredmetne povezave z matematiko na razredni stopnji. [Cross-curricular links with mathematics at the grade level]. University of Primorska.

Žakelj, A., Prinčič Rőhler, A., Perat, Z., Lipovec, A., Vršič, V., Repovž, B., Senekovič, J., \& Bregar Umek, Z. (2011). Program osnovna šola Matematika Učni načrt. [Elementary school maths curriculum Slovenia]. Ljubljana. https://www.gov.si/assets/ministrstva/MIZS/Dokumenti/Osnovna-sola/Ucninacrti/obvezni/UN matematika.pdf 